\title{
HUBUNGAN SANITASI LINGKUNGAN DENGAN KEJADIAN DIARE PADA BALITA
}

\author{
(THE RELATIONSHIP OF ENVIRONMENTAL SANITATION AND THE INCIDENCE OF \\ DIARRHEA IN INFANTS)
}

\section{$\underline{\text { Lili Amaliah }}$}

Sekolah Tinggi Ilmu Kesehatan Mahardika, Cirebon

E-mail: rayhan_imoet@yahoo.co.id

Background: Diarrheal disease is still one of the major causes of morbidity and mortality. Almost all geographic regions of the world and all age groups attacked diarrhea, but severe disease with high mortality primarily found in infants and toddlers. Diarrheal disease is a disease that based environment. Several factors related to the incidence of diarrhea is inadequate water supply, water contaminated by feces, the lack of sanitation (excreta disposal unhygienic), personal hygiene and bad environmental, food preparation undercooked and storage of food cook at room temperature is not should.

Purpose: The purpose of this study was to investigate the relationship environmental sanitation with the incidence of diarrhea in infants.

Method: This research is in the form of observational survey with cross-sectional approach. The subject of this research houses who have children and reside in Puskesmas Mundu Cirebon. Total population of the house who have children and reside in Puskesmas Mundu Cirebon as many as 6021 children under five. the sampling is done using random sampling techniques Stratefied that the sample in this study, there are 98 people. Data collected from interviews using questionnaires and analyzed statistically using Chi square test significant level of $p>0.05$ (95\% confidence level).

Result: The result showed no relationship between drinking water, latrine ownership and type of floor of the house with the incidence of diarrhea in infants in Puskesmas Mundu Cirebon. There is no relationship between the physical quality of water with the incidence of diarrhea in infants in the work area of the health center mundu Cirebon Distric.

Keywords : environmental sanitation, infants, the incidence of diarrhea

Corresponding Author : Lili Amaliah

E-mail: rayhan_imoet@yahoo.co.id
ISSN : 2614-1663

11
e-ISSN : 2355-0724 


\section{PENDAHULUAN}

Penyakit diare sampai saat ini masih merupakan salah satu penyebab utama kesakitan dan kematian. Hampir seluruh daerah geografis dunia dan semua kelompok usia diserang diare, tetapi penyakit berat dengan kematian yang tinggi terutama didapatkan pada bayi dan anak balita. Di negara Amerika Utara anak-anak menderita diare lebih dari 12 kali pertahun (Pitono. A.J, dkk. 2008). Diare menyebabkan kematian sebesar $15-34 \%$ dari semua kematian, kurang lebih 300 kematian per tahun (Zubir, Juffrie M, Wibowo T. 2006). Berdasarkan hasil penelitian Ratnawati D, Trisno A W, Solikhah. 2009 menunjukkan bahwa 35\% dari seluruh kematian balita disebabkan oleh diare akut.

Di Indonesia penyakit diare juga masih menjadi masalah di bidang kesehatan. Angka kesakitan diare sekitar 15-43\% tiap tahun. Dari jumlah tersebut $60-80 \%$ diderita oleh anak balita. Penyakit ini dapat disebabkan oleh berbagai faktor penyebab antara lain virus, bakteri, parasit, jamur, alergi makanan, minuman maupun obat-obatan serta faktor penyebab lainnya seperti keadaan gizi, hiegine dan sanitasi, sosial budaya, musim dan sosial ekonomi. Di Indonesia diare merupakan salah satu penyebab kematian pada anak diantaranya karena infeksi rotavirus. Hasil Riskesdas 2007 bahwa diare merupakan penyebab kematian bayi tertinggi yaitu $42 \%$ dibanding Pneumonia sebesar $24 \%$. Pada golongan umur 1-4 tahun sebanyak 25,2\% kasus kematian disebabkan diare dan $15,5 \%$ disebabkan oleh pneumonia (Zubir, Juffrie M, Wibowo T. 2006).

Kejadian diare pada setiap balita per tahunnya adalah 1,6-2 kali kejadian. Diperkirakan kejadian diare sebanyak 40 juta setiap tahunnya dengan jumlah kematian 200.000-400.000 balita. Pada tahun 2008 dilaporkan bahwa telah terjadi KLB diare di 15 provinsi dengan penderita berjumlah 8.443 orang, dengan jumlah kematian 209 orang atau Case Fatality Rate (CFR) 2,48\%. Diare selalu masuk dalam 10 besar masalah kesehatan dan penyakit yang terjadi pada seluruh puskesmas di Indonesia bersama Infeksi Saluran Pernafasan Akut (ISPA). Masalah ini disebabkan oleh ketidaktahuan dan ketidakmampuan masyarakat dalam memelihara kesehatan lingkungan misalnya pembuangan kotoran, air limbah, pembuangan sampah dan penyediaan air bersih, yang akan berpengaruh terhadap kondisi kesehatan khususnya tingginya masalah penyakit infeksi pencernaan diantaranya penyakit diare.

Cakupan penemuan diare di Jawa Barat mengalami peningkatan sejak tahun 2013 sampai dengan 2015 meskipun masih di bawah yang diharapkan (100\%) yaitu sebesar 80\%. Hal ini disebabkan belum maksimalnya penemuan penderita diare baik oleh kader, puskesmas, rumah sakit swasta maupun pemerintah. Jumlah kasus diare pada balita setiap tahunnya rata-rata di atas $40 \%$ dari jumlah cakupan penemuan penderita diare yaitu pada tahun 2014 sebesar $40,6 \%$ dan tahun 2015 sebesar 48,1\% (Dinas Kesehatan Kabupaten Cirebon. 2015). Berdasarkan data dari Dinas Kesehatan Kabupaten Cirebon pada tahun 2015 jumlah penderita diare sebanyak 16.489 kasus, untuk diare pada balita sebesar 4.259 kasus.

Penyakit diare merupakan penyakit yang berbasis lingkungan. Beberapa faktor yang berkaitan dengan kejadian diare yaitu tidak memadainya penyediaan air bersih, air tercemar oleh tinja, kekurangan sarana kebersihan (pembuangan tinja yang tidak higienis), kebersihan perorangan dan lingkungan yang jelek, penyiapan makanan kurang matang dan penyimpanan makanan masak pada suhu kamar yang tidak semestinya (Sander MA. 2005). Banyak faktor yang secara langsung maupun tidak langsung menjadi pendorong terjadinya diare yaitu faktor agent, pejamu, lingkungan dan perilaku. Faktor lingkungan merupakan faktor yang paling dominan yaitu sarana penyediaan air bersih dan pembuangan tinja, kedua faktor berinteraksi bersama dengan perilaku manusia. Apabila faktor lingkungan tidak sehat karena tercemar kuman diare serta terakumulasi dengan perilaku manusia yang tidak sehat, maka penularan diare dengan mudah dapat terjadi (Zubir, Juffrie M, Wibowo T. 2006).

Berdasarkan hasil penelitian Juariah (2000), diketahui bahwa ada hubungan bermakna antara kesakitan diare dengan sumber air bersih, kepemilikan jamban, jenis lantai, pencahayaan rumah dan ventilasi rumah. Rahadi (2005) menyimpulkan bahwa ada hubungan antara kepemilikan jamban, jarak Saluran Pembuangan Akhir Limbah (SPAL), jenis lantai dengan kejadian diare. Berdasarkan hasil penelitian Wibowo et al (2004) diketahui bahwa ada hubungan yang bermakna antara terjadinya diare dengan pembuangan tinja dan jenis sumber air minum.

Puskesmas Mundu merupakan salah satu wilayah yang jumlah penderita diarenya mengalami peningkatan dari tahun 2015 - 2016 yaitu sebanyak 670 orang menjadi 720 orang.

Berdasarkan data Puskesmas Mundu, jumlah penderita diare pada balita di Kecamatan Mundu tahun 2015 sebanyak 670 balita, tahun 2016 sebanyak 720 balita (Puskesmas Mundu. 2015). Cakupan sanitasi dasar di UPT Puskesmas Mundu Kabupaten Cirebon Tahun 2016 yaitu air bersih $75 \%$ dari target nasional $80 \%$, rumah sehat $70 \%$ dari target nasional $80 \%$, jamban keluarga yang memenuhi syarat kesehatan $60 \%$ dari target nasional $75 \%$, tempat pengelolaan sampah $70 \%$ dari target nasional 80\% dan SPAL 66\% dari target nasional 80\% (Puskesmas Mundu. 2015). 
Berdasarkan uraian di atas maka peneliti tertarik untuk melakukan penelitian mengenai hubungan antara sanitasi lingkungan dengan kejadian diare pada balita di Wilayah Kerja Puskesmas Mundu Kabupaten Cirebon Tahun 2017.

\section{METODE PENELITIAN}

Penelitian ini merupakan penelitian dalam bentuk survey yang bersifat observasional dengan metode pendekatan cross-sectional. Variabel bebas dalam penelitian ini adalah sanitasi lingkungan yang meliputi sumber air minum, kualitas fisik air bersih, kepemilikan jamban dan jenis lantai rumah. Variabel terikat dalam penelitian ini adalah kejadian diare pada balita di wilayah kerja Puskesmas Mundu Kabupaten Cirebon. Populasi dalam penelitian ini adalah rumah yang memiliki balita dan bertempat tinggal di wilayah kerja Puskesmas Mundu Kabupaten Cirebon pada Tahun 2016 yaitu sebanyak 6.021 balita. Teknik pengambilan sampel yang digunakan pada penelitian ini adalah menggunakan Proporsional Random Sampling dengan jumlah sampel 98 balita.

Instrumen yang digunakan dalam penelitian ini adalah kuisioner dan lembar Check List. Kuisioner dalam penelitian diadopsi dari peneliti lain yaitu Bhakti Rochman Tri Bintoro dengan judul "Hubungan antara sanitasi lingkungan dengan kejadian diare pada balita di Kecamatan Jatipuro Kabupaten Karanganyar Tahun 2010" dengan hasil uji validitas dan realibilitas $r_{x y} 0,947$. Analisis yang digunakan adalah uji statistik chi square.

\section{HASIL PENELITIAN}

1. Hasil Analisa Univariat

a. Sumber Air Minum

Tabel 1

Distribusi Frekuensi Sumber Air Minum Responden di Wilayah Kerja Puskesmas Mundu Kabupaten Cirebon

\begin{tabular}{llc}
\hline \multirow{2}{*}{$\begin{array}{l}\text { Sumber Air } \\
\text { minum }\end{array}$} & \multicolumn{2}{c}{ Responden } \\
\cline { 2 - 3 } 1. Terlindung & 26 & $\mathbf{f}$ \\
\hline 2. Tidak terlindung & 72 & 73,5 \\
\hline Total & $\mathbf{9 8}$ & $\mathbf{1 0 0}$ \\
\hline
\end{tabular}

Berdasarkan Tabel 1 diketahui bahwa sumber air minum responden diperoleh dari mata air yang tidak terlindung, yaitu sebanyak 73,5\% dan diperoleh dari mata air terlindung, yaitu sebanyak $26,5 \%$.

\section{b. Kualitas Fisik Air Bersih}

Tabel 2

\begin{tabular}{|c|c|c|c|}
\hline & \multirow[t]{2}{*}{ Kualitas fisik air bersih } & \multicolumn{2}{|c|}{ Responden } \\
\hline & & $\mathbf{f}$ & $(\%)$ \\
\hline 1. & Memenuhi syarat & 47 & 48,0 \\
\hline \multirow[t]{2}{*}{2 . } & Tidak memenuhi syarat & 51 & 52,0 \\
\hline & Total & 98 & 100 \\
\hline
\end{tabular}

Distribusi Frekuensi Kualitas Fisik Air Bersih
Responden di Wilayah Kerja Puskesmas Mundu
Kabupaten Cirebon

Berdasarkan Tabel 2 diketahui bahwa kualitas fisik air bersih pada responden yang tidak memenuhi syarat, yaitu sebanyak $52,0 \%$ dan yang sudah memenuhi syarat yaitu sebanyak $48,0 \%$.

c. Kepemilikan Jamban

Tabel 3

Distribusi Frekuensi Kepemilikan Jamban Responden di Wilayah Kerja Puskesmas Mundu Kabupaten Cirebon

\begin{tabular}{llrc}
\hline \multirow{2}{*}{ Kepemilikan Jamban } & \multicolumn{2}{c}{ Responden } \\
\cline { 3 - 4 } & & $\mathbf{f}$ & $(\boldsymbol{\%})$ \\
\hline 1. & Memiliki & 57 & 58,2 \\
2. & Tidak memiliki & 41 & 41,8 \\
\hline \multicolumn{2}{c}{ Total } & $\mathbf{9 8}$ & $\mathbf{1 0 0}$ \\
\hline
\end{tabular}

Berdasarkan Tabel 3 diketahui bahwa responden yang sudah memiliki jamban, yaitu sebanyak 58,2\% dan yang belum memiliki jamban, yaitu sebanyak $41,8 \%$. 
Tabel 6

d. Jenis lantai rumah

Hubungan antara sumber air minum dengan kejadian diare pada balita di Wilayah Kerja

Tabel 4

Distribusi Frekuensi Jenis Lantai Rumah Responden di Wilayah Kerja Puskesmas Mundu Puskesmas Mundu Kabupaten Cirebon Kabupaten Cirebon

\begin{tabular}{|c|c|c|c|c|c|c|c|c|c|c|}
\hline \multirow{2}{*}{ Jenis lantai rumah } & \multicolumn{2}{|c|}{ Responden } & & & & & & & & \\
\hline & $\mathbf{f}$ & $(\%)$ & & & & & & & & \\
\hline 1. Kedap air & 54 & 55,1 & & & & & & & & \\
\hline 2. Tidak kedap air & 44 & 44,9 & & & & & & & & \\
\hline Total & 98 & 100 & & & & & & & & \\
\hline \multirow{2}{*}{\multicolumn{3}{|c|}{$\begin{array}{l}\text { Berdasarkan Tabel } 4 \text { diketahui bahwa jenis } \\
\text { lantai rumah responden telah memiliki lantai yang } \\
\text { kedap air, yaitu sebanyak } 55,1 \% \text { dan yang memiliki } \\
\text { lantai yang tidak kedap air, yaitu sebanyak } 44,9 \% \text {. }\end{array}$}} & $\begin{array}{c}\text { Sumber air } \\
\text { minum }\end{array}$ & \multicolumn{2}{|c|}{ Diare } & \multicolumn{2}{|c|}{$\begin{array}{l}\text { Tidak } \\
\text { diare }\end{array}$} & & & \\
\hline & & & & $\mathbf{f}$ & $\%$ & $\mathbf{f}$ & $\%$ & f & $\%$ & \\
\hline \multicolumn{3}{|c|}{ e. Kejadian diare pada balita } & $\begin{array}{l}\text { Terlindung } \\
\text { Tidak } \\
\text { terlindung }\end{array}$ & $\begin{array}{c}6 \\
64\end{array}$ & $\begin{array}{l}6,1 \\
65,3\end{array}$ & $\begin{array}{r}20 \\
8\end{array}$ & $\begin{array}{r}20,4 \\
8,2\end{array}$ & $\begin{array}{l}26 \\
72\end{array}$ & $\begin{array}{l}26,5 \\
73,5\end{array}$ & 0,001 \\
\hline \multicolumn{3}{|c|}{$\begin{array}{c}\text { Tabel } 5 \\
\text { Distribusi Frekuensi Kejadian diare pada balita } \\
\text { di Wilayah Kerja Puskesmas Mundu }\end{array}$} & Total & 70 & 71,4 & 28 & 28,6 & 98 & 100 & \\
\hline
\end{tabular}
Kabupaten Cirebon

Berdasarkan tabel 6 didapatkan hasil bahwa

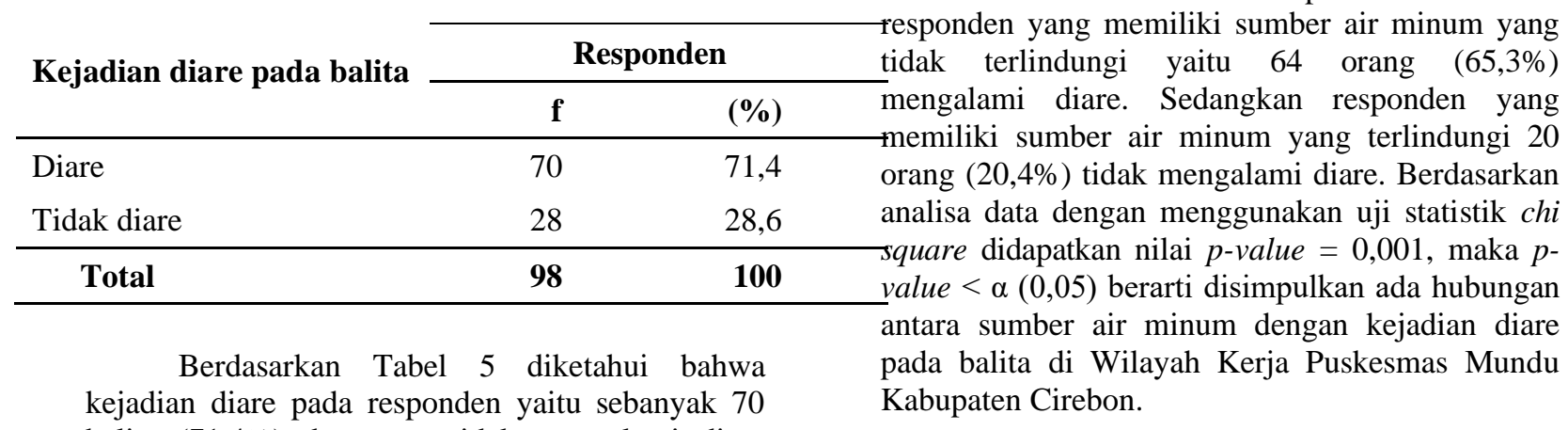
balita $(71,4 \%)$ dan yang tidak mengalami diare yaitu sebanyak $28,6 \%$.

2. Hasil Analisa Bivariat

2.1 Hubungan antara sumber air minum dengan kejadian diare pada balita
2.2 Hubungan antara kualitas fisik air bersih dengan kejadian diare pada balita.

Tabel 7

Hubungan antara Kualitas Fisik Air Bersih dengan Kejadian Diare pada Balita di Wilayah Kerja Puskesmas Mundu Kabupaten Cirebon

\begin{tabular}{|c|c|c|c|c|c|c|c|}
\hline \multirow{3}{*}{$\begin{array}{c}\text { Kualitas fisik } \\
\text { air bersih }\end{array}$} & \multicolumn{4}{|c|}{ Kejadian } & \multirow{2}{*}{\multicolumn{2}{|c|}{ Total }} & \multirow[t]{3}{*}{$\mathbf{p}$} \\
\hline & \multirow{2}{*}{\multicolumn{2}{|c|}{$\begin{array}{l}\text { Diare } \\
1 \%\end{array}$}} & \multicolumn{2}{|c|}{ Tidak } & & & \\
\hline & & & $\mathbf{f}$ & $\%$ & $\mathbf{f}$ & $\%$ & \\
\hline Memenuhi & 22 & 22,4 & 25 & 25,6 & 47 & 48,0 & 0,307 \\
\hline $\begin{array}{l}\text { Tidak } \\
\text { memenuhi }\end{array}$ & 48 & 49,0 & 3 & 3,0 & 51 & 52,0 & \\
\hline Total & 70 & 71,4 & 2 & 28, & 98 & 100 & \\
\hline
\end{tabular}


Berdasarkan tabel 7 didapatkan hasil bahwa responden yang tidak memenuhi kualitas fisik air bersih yaitu 48 orang $(49,0 \%)$ mengalami diare. Sedangkan responden yang memenuhi kualitas fisik air bersih yaitu 25 orang $(25,6 \%)$ tidak mengalami diare. Berdasarkan analisa data dengan Kedap air menggunakan uji statistik chi square didapatkannilai $p$-value $=0,307$, maka $p$-value $>\alpha(0,05)$ berarti disimpulkan tidak ada hubungan antara Total kualitas fisik air bersih dengan kejadian diare pada balita di Wilayah Kerja Puskesmas Mundu Kabupaten Cirebon.

\begin{tabular}{|c|c|c|c|c|c|c|c|}
\hline \multirow{3}{*}{$\begin{array}{c}\text { Jenis Lantai } \\
\text { Rumah }\end{array}$} & \multicolumn{4}{|c|}{ Kejadian diare } & \multicolumn{2}{|c|}{ Total } & \multirow[t]{3}{*}{$\mathbf{p}$} \\
\hline & \multicolumn{2}{|c|}{ Diare } & \multicolumn{2}{|c|}{ Tidak diare } & & & \\
\hline & 1 & $\%$ & f & $\%$ & f & $\%$ & \\
\hline Kedap air & 33 & 33,7 & 21 & 21,4 & 54 & 55,1 & 0,036 \\
\hline Tidak kedap air & 37 & 37,8 & 7 & 7,1 & 44 & 44,9 & \\
\hline Total & 70 & 71,4 & 28 & 28,6 & 98 & 100 & \\
\hline
\end{tabular}

\subsection{Hubungan antara kepemilikan jamban dengan kejadian diare pada balita.}

Tabel 8

Hubungan antara Kepemilikan Jamban dengan Kejadian Diare pada Balita di Wilayah Kerja Puskesmas Mundu Kabupaten Cirebon

Berdasarkan tabel 9 didapatkan hasil bahwa responden yang memiliki jenis lantai rumah tidak kedap air yaitu 37 orang $(37,8 \%)$ mengalami diare. Sedangkan yang memiliki jenis lantai rumah kedap air sebanyak 33 orang $(33,7 \%)$ mengalami diare. Berdasarkan analisa data dengan menggunakan uji statistik chi square didapatkan nilai $p$-value $=0,036$, maka $p$-value $<\alpha(0,05)$ berarti disimpulkan ada hubungan antara jenis lantai rumah dengan kejadian diare pada balita di Wilayah Kerja Puskesmas Mundu Kabupaten

\begin{tabular}{|c|c|c|c|c|c|c|}
\hline \multirow{3}{*}{$\begin{array}{l}\text { Kepemilikan } \\
\text { jamban }\end{array}$} & \multicolumn{5}{|c|}{ Kejadian diare } & \multirow[t]{2}{*}{ Total } \\
\hline & \multicolumn{3}{|c|}{ Diare } & \multicolumn{2}{|c|}{$\begin{array}{r}\text { Tidak } \\
\text { diare }\end{array}$} & \\
\hline & & $\%$ & $\mathbf{f}$ & $\%$ & & $\%$ \\
\hline Memiliki & 37 & 37,8 & 20 & 20,4 & 57 & $58,2 \quad 0,018$ \\
\hline $\begin{array}{l}\text { Tidak } \\
\text { memiliki }\end{array}$ & 33 & 33,6 & 8 & 8,2 & 41 & 41,8 \\
\hline Total & 70 & 71,4 & 28 & $\begin{array}{r}28, \\
6\end{array}$ & 98 & 100 \\
\hline
\end{tabular}

Berdasarkan tabel 8 didapatkan hasil bahwa responden yang memiliki jamban yaitu 37 orang $(37,8 \%)$ mengalami diare. Sedangkan yang tidak memiliki jamban yaitu 33 orang $(33,6 \%)$ mengalami diare. Berdasarkan analisa data dengan menggunakan uji statistik chi square didapatkan nilai $p$-value $=0,018$, maka $p$ value $<\alpha(0,05)$ berarti disimpulkan ada hubungan antara kepemilikan jamban dengan kejadian diare pada balita di wilayah Kerja Puskesmas Mundu Kabupaten Cirebon.

\subsection{Hubungan antara jenis lantai rumah dengan kejadian diare pada balita}

Tabel 9

Hubungan antara jenis lantai rumah dengan Kejadian Diare pada Balita di Wilayah Kerja Puskesmas Mundu Kabupaten Cirebon Cirebon.

\section{PEMBAHASAN}

Hubungan antara Sumber Air Minum dengan Kejadian Diare pada Balita

Berdasarkan analisa data dengan menggunakan uji statistik chi square didapatkan nilai $p$-value $=0,001$, maka $p$-value $<\alpha(0,05)$ berarti disimpulkan ada hubungan antara sumber air minum dengan kejadian diare pada balita di Wilayah Kerja Puskesmas Mundu Kabupaten Cirebon Tahun 2017.

Hasil penelitian ini sejalan dengan hasil penelitian Sutomo (1987) disimpulkan bahwa ada hubungan antara sumber air minum yang dikonsumsi di rumah-rumah pada daerah pedesaan dan responden yang menggunakan air bersih memiliki kecenderungan lebih kecil menderita penyakit diare. Sebaliknya responden yang tidak menggunakan air bersih memiliki kecenderungan menderita penyakit diare.

Hasil penelitian lain yang serupa adalah Zubir (2006) penelitian mengenai faktor-faktor risiko kejadian diare akut pada anak 0-35 bulan (Batita) di Kabupaten Bantul. Hasil penelitian menunjukkan bahwa sumber air minum yang digunakan berhubungan dengan terjadinya diare akut dengan nilai $\mathrm{p}<0,05$ dan besarnya Rasio Prevalensi sebesar 3,10. Hasil penelitian lain yang sejalan adalah penelitian Wibowo et. al (2004) menyimpulkan bahwa ada hubungan yang bermakna antara kejadian diare dengan jenis sumber air minum.

Air merupakan hal yang sangat penting bagi manusia. Kebutuhan manusia akan air sangat komplek antara lain untuk minum, masak, 
mencuci, mandi dan sebagainya. Di antara kegunaan-kegunaan air tersebut, yang sangat penting adalah kebutuhan untuk minum.Oleh karena itu, untuk keperluan minum (termasuk untuk memasak) air harus mempunyai persyaratan khusus agar air tersebut tidak menimbulkan penyakit bagi manusia termasuk diare. ${ }^{12}$

Sumber air minum utama merupakan salah satu sarana sanitasi yang tidak kalah pentingnya berkaitan dengan kejadian diare. Sebagian kuman infeksius penyebab diare ditularkan melalui jalur fekal oral. Mereka dapat ditularkan dengan memasukkan ke dalam mulut, cairan atau benda yang tercemar dengan tinja, misalnya air minum, jari-jari tangan, dan makanan yang disiapkan dalam panci yang dicuci dengan air tercemar. ${ }^{12}$

Sumber air minum merupakan salah satu sarana sanitasi yang tidak kalah pentingnya berkaitan dengan kejadian diare. Sebagian kuman infeksius penyebab diare ditularkan melalui jalur fekal oral. Mereka dapat ditularkan dengan memasukkan ke dalam mulut, cairan atau benda yang tercemar dengan tinja, misalnya air minum, jari-jari tangan, dan makanan yang disiapkan dalam panci yang dicuci dengan air tercemar.

Hubungan antara Kualitas fisik air bersih dengan Kejadian Diare pada Balita

Berdasarkan analisa data dengan menggunakan uji statistik chi square didapatkan nilai $p$-value $=0,307$, maka $p$-value $>\alpha(0,05)$ berarti disimpulkan tidak ada hubungan antara kualitas fisik air bersih dengan kejadian diare pada balita di Wilayah Kerja Puskesmas Mundu Kabupaten Cirebon Tahun 2017.

Berdasarkan hasil penelitian Rahadi (2005) bahwa air mempunyai peranan besar dalam penyebaran beberapa penyakit menular. Besarnya peranan air dalam penularan penyakit disebabkan keadaan air itu sendiri sangat membantu dan sangat baik untuk kehidupan mikroorganisme. Hal ini dikarenakan sumur penduduk tidak diplester dan tercemar oleh tinja.

Banyaknya sarana air bersih berupa sumur gali yang digunakan masyarakat mempunyai tingkat pencemaran terhadap kualitas air bersih dengan kategori tinggi dan amat tinggi.

Hubungan antara kepemilikan jamban dengan Kejadian Diare pada Balita

Berdasarkan analisa data dengan menggunakan uji statistik chi square didapatkan nilai $p$-value $=0,018$, maka $p$-value $<\alpha(0,05)$ berarti disimpulkan ada hubungan antara kepemilikan jamban dengan kejadian diare pada balita di wilayah Kerja Puskesmas Mundu Kabupaten Cirebon Tahun 2017.

Hasil penelitian ini sejalan dengan hasil penelitian Rahadi (2005) yang menyimpulkan bahwa ada hubungan antara kepemilikan jamban dengan kejadian diare di Desa Panganjaran
Kabupaten Kudus,yaitu sebanyak 68,7\% penduduk telah memiliki jamban keluarga. Kejadian diare pada balita ini disebabkan karena sebanyak 22,1\% tinja manusia dibuang di kebun atau pekarangan rumah.

Penelitian lain yaitu Zubir et, al (2006) menyimpulkan bahwa selain sumber air minum tempat pembuangan tinja juga merupakan sarana sanitasi yang penting dalam mempengaruhi kejadian diare. Membuang tinja yang tidak memenuhi syarat sanitasi dapat mencemari lingkungan pemukiman, tanah dan sumber air. Dari lingkungan yang tercemar tinja berakumulasi dengan perilaku manusia yang tidak sehat, tidak mencuci tangan dengan sempurna setelah bekerja atau bermain di tanah (anak-anak), melalui makanan dan minuman maka dapat menimbulkan kejadian diare. Hasil penelitian ini juga sejalan dengan penelitian Wibowo et.al (2004) disimpulkan ada hubungan yang bermakna antara kejadian diare dengan tempat pembuangan tinja.

Syarat pembuangan kotoran yang memenuhi aturan kesehatan adalah tidak mengotori permukaan tanah di sekitarnya, tidak mengotori air permukaan di sekitarnya, tidak mengotori air dalam tanah di sekitarnya, kotoran tidak boleh terbuka sehingga dapat dipakai sebagai tempat vektor bertelur dan berkembangbiak.

Dengan belum memiliki jamban sendiri, dapat menyebabkan timbulnya kejadian diare pada balita responden yang dikarenakan kotoran tinja yang tidak terkubur rapat akan mengundang lalat maupun tikus yang akan berdampak terhadap kesehatan lingkungan.

Hubungan antara jenis lantai dengan Kejadian Diare pada Balita

Berdasarkan analisa data dengan menggunakan uji statistik chi square didapatkan nilai $p$-value $=0,036$, maka $p$-value $<\alpha(0,05)$ berarti disimpulkan ada hubungan antara jenis lantai rumah dengan kejadian diare pada balita di Wilayah Kerja Puskesmas Mundu Kabupaten Cirebon Tahun 2017.

Hasil penelitian ini sejalan dengan hasil penelitian Rahadi (2005) yang menyimpulkan bahwa jenis lantai berhubungan dengan kejadian diare. Hal ini disebabkan karena masih banyak lantai yang terbuat dari tanah yang akan menyebabkan ruang kotor dan menjadi sarang mikroorganisme serta mudah menyerap air yang mungkin air tersebut mengandung mikroorganisme.

Berdasarkan hasil penelitian Juariah (2000), diketahui bahwa ada hubungan bermakna antara kesakitan diare dengan sumber air bersih, kepemilikan jamban, jenis lantai, pencahayaan rumah dan ventilasi rumah.

Syarat rumah yang sehat jenis lantai yang tidak berdebu pada musim kemarau dan tidak basah pada musim penghujan. Dengan banyaknya responden yang memiliki lantai rumah yang masih 
tidak kedap air sangat memungkinkan lantai menjadi sarang kuman, debu untuk dapat menjadi pencetus terjadinya diare pada balita. Aktivitas balita responden yang bermain di lantai rumah menyebabkan terjadikan kontak antara lantai rumah yang tidak kedap air dengan tubuh balita. Keadaan ini memunculkan berbagai kuman penyakit yang menempel pada tubuh balita. Kondisi yang tidak baik dapat menyebabkan terjadinya diare pada balita.

\section{SIMPULAN DAN SARAN}

\section{Simpulan}

Berdasarkan hasil penelitian maka dapat ditarik simpulan sebagai berikut:

1. Ada hubungan antara sumber air minum dengan kejadian diare pada balita.

2. Tidak ada hubungan antara kualitas fisik air bersih dengan kejadian diare pada balita.

3. Ada hubungan antara kepemilikan jamban keluaraga dengan kejadian diare pada balita.

4. Ada hubungan antara jenis lantai rumah dengan kejadian diare pada balita.

\section{Saran}

Berdasarkan simpulan diatas, maka saran yang dapat diberikan peneliti adalah sebagai berikut:

Puskesmas

1. UPT Puskesmas Mundu melalui Dinas Kesehatan memberikan masukan pada Dinas Tata Ruang dan Bangunan agar dalam pemberian IMB (Ijin Mendirikan Bangunan) ada persyaratan minimal rumah sehat.

2. Bersama dengan masyarakat/pemerintah desa, berusaha untuk mencari sumber air, berupaya mencari jalan kemudahan bagi masyarakat untuk mendapatkan air bersih bagi lingkungannya dan membentuk kelompok pemakai air (pokmair misalnya) untuk mengawasi sumber air, memelihara saluran air dan memperbaiki kerusakan bilamana terjadi

3. Menggalang pihak lain, termasuk dunia usaha untuk memberi bantuan dalam penyedian air bersih serta pembangunan jamban dan rumah sehat.

\section{Masyarakat}

Meningkatkan tindakan pencegahan terjadinya diare dengan menjaga kebersihan lingkungan dan melakukan pengolahan air sampai mendidih sebelum air dikonsumsi.

\section{Peneliti Lain}

Mengadakan penelitian lebih lanjut mengenai permasalahan yang sama, namun dengan variabel yang lain dalam hubungannya kejadian diare pada balita. Variabel lain seperti tingkat pendapatan responden dan faktor budaya.

\section{DAFTAR PUSTAKA}

Pitono. A.J, dkk. 2008. Penatalaksanaan Diare di Rumah pada Balita . Berita Kedokteran Masyarakat.Vol.22.No.1.Maret 2006:7-14.

Zubir, Juffrie M, Wibowo T. 2006. Faktor-faktor Resiko Kejadian Diare Akut pada Anak 0-35 Bulan (BATITA) di Kabupaten Bantul. Sains Kesehatan. Vol 19. No 3. Juli 2006. ISSN 1411$6197: 319-332$.

Ratnawati D, Trisno A W, Solikhah. 2009. Faktor Risiko Kejadian Akut pada Balita di Kabupaten Kulonprogo. Diakses: 18 Mei 2009. http://www.kapanlagi.com/h/000015 3644.htm.

Dinas Kesehatan Kabupaten Cirebon. 2015. Profil Kesehatan Kabupaten Cirebon. Kabupaten Cirebon.

Sander MA. 2005. Hubungan Faktor Sosio Budaya dengan Kejadian Diare di Desa Candinegoro Kecamatan Wonoayu Sidoarjo. Medika. Vol. 2. No.2. JuliDesember 2005:163-171

Juariah S. 2000. Hubungan Sanitasi Lingkungan dengan Kejadian Diare pada Anak Balita di Kelurahan Bandarharjo Kecamatan Semarang Utara Kota Semarang. (Skripsi) Universitas Diponegoro. Diakses: 18 Juli 2016. http://www.fkm.undip.ac.id/data/inde x.php?action $=4 \&$ idx $=1317$.

Rahadi E B. 2005. Hubungan Sanitasi Rumah dengan Kejadian Diare di Desa Peganjaran Kecamatan Bae Kabupaten Kudus Tahun 2005. (KTI) UMS. Diakses: 18 Juli 2016. http://etd.library.ums.ac.id/gdl.php? mod=browse \&op=read\&id=jtptumsgdl-sl-2007-ekobagusra-9071.

Wibowo T, Soenarto S \& Pramono D. 2004. Faktor-faktor Resiko Kejadian Diare Berdarah pada Balita di Kabupaten Sleman. Berita Kedokteran Masyarakat. Vol. 20. No.1. Maret 2004: 41-48.

Puskesmas Mundu. 2015. Profil Puskesmas Mundu. Kabupaten Cirebon.

Suraatmaja S. 2007. Kapita Selekta Gastroentrologi. Jakarta: CV. Sagung 


\section{Lili Amaliah}

Jurnal Kesehatan Mahardika Vol. 6 No. 1 Februari 2019

Seto.

Widoyono. 2008. Penyakit Tropis Epidemiologi, Penularan, Pencegahan dan Pemberantasannya. Surabaya: Erlangga.

Depkes RI. 2000. Buku Pedoman Pelaksanaan Program P2 Diare. Jakarta: Depkes RI.

Depkes RI. 2005. Buku Pedoman Pelaksanaan Program P2 Diare. Jakarta: Depkes RI

Amiruddin R. 2007. Current Issue Kematian Anak karena Penyakit Diare (Skripsi). Universitas Hasanuddin Makasar. Diakses: $23 \quad$ Juli 2016. http://ridwanamiruddin.wordpress. com/2007/10/17/current-issue-matiananak-karena-penyakit-diare/.

Notoatmodjo S. 2003. Ilmu Kesehatan Masyarakat
Prinsip-prinsip Dasar. Jakarta: PT Rineka Cipta.

Timmreck CT. 2004. Epidemiologi suatu Pengantar. Jakarta: Buku Kedokteran EGC.

Slamet JS. 2002. Kesehatan Lingkungan. Yogyakarta : Gajah Mada University Press.

Entjang I. 2000. Ilmu Kesehatan Masyarakat. Jakarta: Citra Aditya Bakti. Ihsan

Machfoedz I. 2007. Metodologi Penelitian Bidang Kesehatan, Keperawatan, dan Kebidanan. Yogyakarta: Fitramaya.

Murti, B. 2006. Desain dan Ukuran Sampel untuk Penelitian Kuantitatif dan Kualitatif. Jogjakarta: Gajah Mada University press 